\title{
Percutaneous endoscopic necrosectomy
}

A 32-year-old man presented to our institution with abdominal pain, anorexia, fevers, and leukocytosis from a large walled-off necrosis. Prior to this presentation he had been admitted to a local hospital 6 weeks previously with acute severe alcohol-related pancreatitis, which entailed a prolonged stay in the intensive care unit due to multiorgan failure. He was found to have an abdominal fluid collection during this admission for which a percutaneous drain had been placed.

An endoscopic cystogastrostomy was performed using a lumen-apposing covered metal stent, with subsequent endoscopic necrosectomies. However, he continued to have persistent systemic inflammatory signs from a large persistent collection in the right upper quadrant of the abdomen with inflammatory stranding. A previously placed percutaneous drain proved to be insufficient for what was mostly solid necrosis. A multidisciplinary decision to perform a percutaneous endoscopic necrosectomy was made. A $10 \mathrm{~cm} \times 18 \mathrm{~mm}$ fully covered metal stent was placed in the track of the percutaneous catheter under fluoroscopic guidance to dilate the track. This was followed, the next day, by a singlesession debridement of the cavity which subsequently resulted in significant clinical improvement and the patient's eventual discharge from the hospital. Complete healing of the fistula track and removal of all external drains was achieved in 4 weeks. The lumen-apposing stent was successfully removed 2 months after placement.

Necrotizing pancreatitis and infected necrotic tissue is associated with a high rate of morbidity and mortality. While about
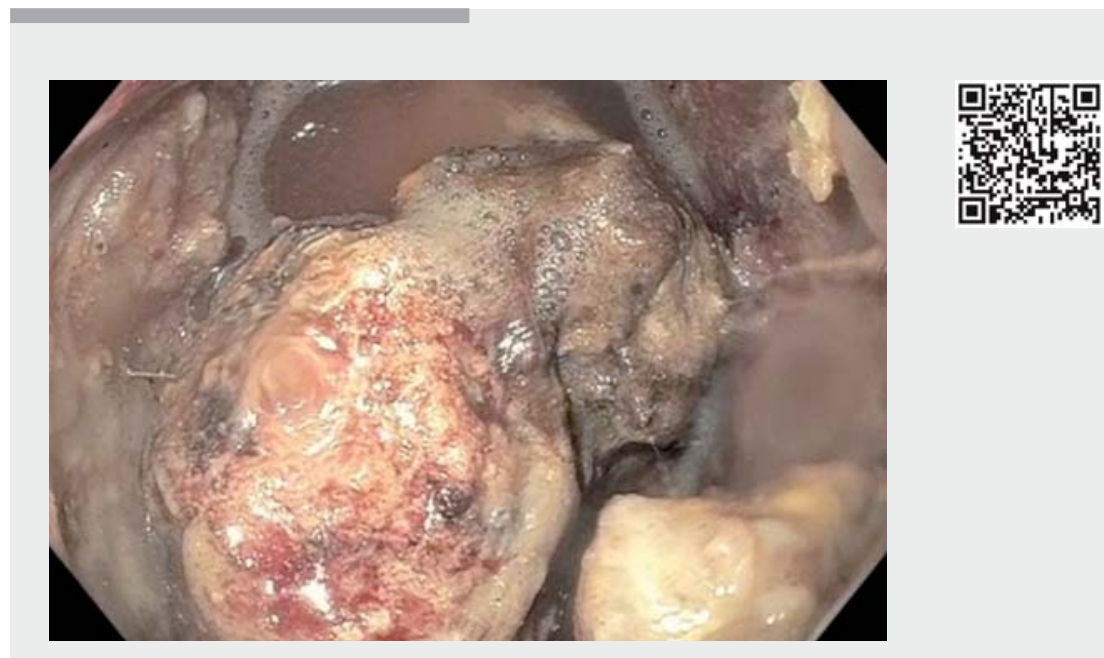

$\checkmark$ Video 1 Percutaneous endoscopic necrosectomy via the track of a previously placed drain.

a third of patients with infected necrosis may respond to percutaneous catheter drainage, the majority tend to require debridement [1]. This has led to the evolution from a morbid open surgical debridement to minimally invasive techniques including the percutaneous flexible endoscopic approach. Two small series have shown this technique to be effective $[2,3]$. Complications included a case of pancreaticocutaneous fistula in each series and self-limited bleeding in one series. Percutaneous endoscopic necrosectomy is an effective adjunct to the management of necrotic pancreatic collections and may especially be considered when percutaneous access has already been achieved by means of a traditional drain.

Endoscopy_UCTN_Code_TTT_1AS_2AD
Competing interests

D. L. Carr-Locke: Constultant for Boston Scientific and Olympus America.

The Authors

Lionel S. D'Souza, Andrew Korman, David L. Carr-Locke, Petros C. Benias

Mount Sinai Beth Israel Medical Center, New York, USA

\section{Corresponding author}

\section{Lionel S. D'Souza, MD}

Mount Sinai Beth Israel Medical Center, 350 East 17th Street, Baird Hall, 17th Floor, New York, NY 10003, USA

Fax: +1-212-4204373

dsouza.lionel@gmail.com 
[1] Van Santvoort HC, Besselink MG, Bakker O] et al. A step-up approach or open necrosectomy for necrotizing pancreatitis. N Engl J Med 2010; 362: 1491 - 1502

[2] Dhingra R, Srivastava S, Behra S et al. Single or multiport percutaneous endoscopic necrosectomy performed with the patient under conscious sedation is a safe and effective treatment for infected pancreatic necrosis (with video). Gastrointest Endosc 2015; 81: 351-359

[3] Mathers B, Moyer M, Mathew A et al. Percutaneous debridement and washout of walled-off abdominal abscess and necrosis using flexible endoscopy: a large singlecenter experience. Endosc Int Open 2016; 4: E102-106

\section{Bibliography}

DOI https://doi.org/10.1055/s-0043-114407

Published online: 18.7.2017

Endoscopy 2017; 49: E242-E243

(c) Georg Thieme Verlag KG

Stuttgart · New York

ISSN 0013-726X

\section{ENDOSCOPY E-VIDEOS}

https://eref.thieme.de/e-videos

回解 Endoscopy E-Videos is a free Fection, reporting 回: on interesting cases and new

techniques in gastroenterological endoscopy. All papers include a high quality video and all contributions are freely accessible online.

This section has its own submission website at

https://mc.manuscriptcentral.com/e-videos 